\title{
The Paris Commune: Lenin's Guide to Revolution
}

\author{
Jeffrey Weng
}

\author{
Dulwich College Beijing, Beijing, 101300, China, Jeffrey. \\ weng22@stu.dulwich.org
}

\begin{abstract}
Throughout history, many have reasoned that the success of the 1917 Russian Revolution may be best attributed to Lenin's forcefulness. Yet, the lack of force and violence across Marx's writings solicit the question: what prompted him to act as such? This paper will argue that Lenin's decisive attitude towards the 1917 revolution stem from his analysis of the Paris Commune's failures, namely, its wavering aims, reluctance to violence, and unconsolidated support.
\end{abstract}

Keywords: Lenin, Marxism, Communism, Paris Commune, Russia.

\section{INTRODUCTION}

Karl Marx has often been regarded as an unparalleled analyst of the capitalist society throughout modern political history. While his ideologies transformed the future of many states and individuals, Marx himself has seldom if ever shared his conjectures about the future, refusing to "[Play] with fantastic pictures of the future structure of society." [1]. His vague portrayal of the future elicits questions: How would capitalism be overcome? Would it happen gradually or all at once? Could it happen through democracy, or would it have to be violent? Revolutionaries around the world inquired these questions. Amongst them was Vladimir Lenin, an enthusiastic Russian revolutionary youth who had recently left exile in 1900. Amidst ideological splits in German Marxism, with revisionists, led by Eduard Bernstein, advocating for peaceful, democratic means to obtain socialism, Vladimir Lenin insisted that a revolution should be forceful and violent. However, the absence of an anticipated violent revolution within Marx's works raises the question: where did Lenin get this idea? Historians have always been fascinated with the Paris Commune and its relationship to Lenin. Some historians have argued that the Commune was used as propaganda for the Soviet government, whose efforts stem from their hopes to compensate for the party's lack of historical background. Others have argued that while Lenin was somewhat inspired by the Commune, its impact was insignificant to solicit a genuine change in Lenin's ideologies. [2] However, most historians who studied the Commune have focused their attention on investigating the effects of the Commune on Marx, the embodiment of communism, rather than Lenin. In this paper, I will analyze the direct impact of the Commune on Lenin and indirectly via Marx and its effects on Lenin's actions. I will argue that Lenin's idea of the revolutionary vanguard and their violent, forceful means stemmed from his analysis of the Paris Commune, and most importantly, its failures.

\section{THE PARIS COMMUNE}

On September 2, 1870, Emperor Napoleon III, the acting Regent Empress Engénie, was captured following the humiliating defeat at the Battle of Sedan. Ensuing his capture, the deputies of the National Assembly declared the formation of the new French Republic. Amid the Chao, the National Guard, composed mainly of Parisian workers, was ordered to disarm by the executive leader of the provisional government Adolphe Thiers. The Parisians, humiliated by the Prussian's march across Paris and feeling betrayed by the central government, organized resistance against Thiers's attempts. On March 26, the Central Committee of the guards organized municipal elections. Parisians casted their votes in unison against the central government, electing the revolutionaries, resulting in the subsequent formation of the Commune government. During the Commune's shortlived establishment, the city of Paris enacted progressive policies aimed at establishing social democracy. Namely, separating church from state, improving labor policies, providing free public education, and abolishing bureaucracy by making all officials elective and removable, which Lenin praised in his earliest public remarks of the Commune in 1904. [3] During the Bloody Week on May 21, 1871, over 7000 Communards were killed or executed by the National French Army, leading to the Commune's downfall. While the battle ended the Commune's reign, its legacy prevailed long into the future. 


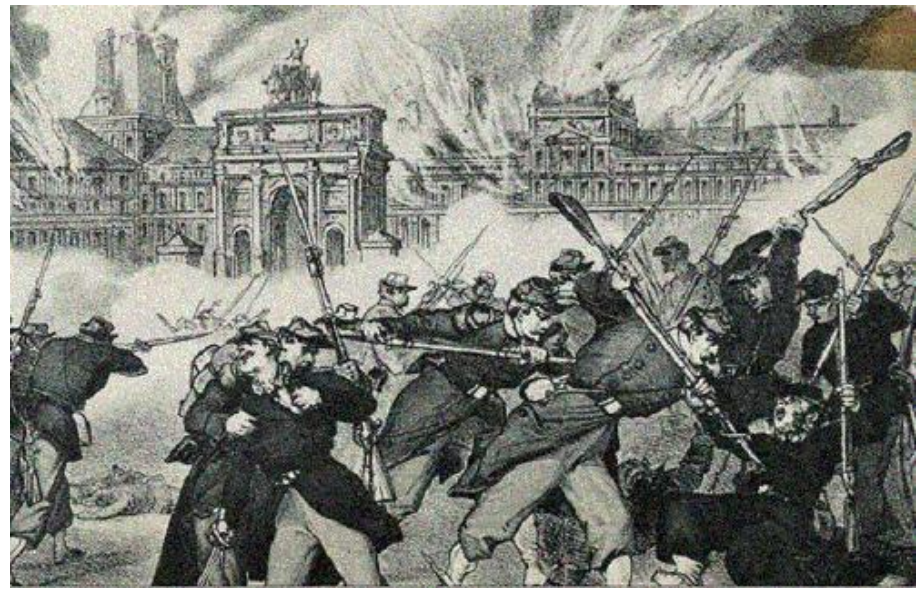

Figure 1. The Paris Commune during the Bloody Week of May 1871

\section{THE PARIS COMMUNE'S EFFECTS ON LENIN'S IDEOLOGIES}

The Commune was not the quintessential revolution under Marx's ideologies. Its spontaneity and unconsolidated aims led itself far astray. In fact, its mere occurrence was of a surprise to Marx, who claimed that England was the only feasible breeding ground for a workers' revolution due to its material conditions, making it crucial for the development of a revolution. [1] Additionally, he later claimed that "any attempt to overthrow the new republic would be a desperate folly." [1] However, it is precisely the unprecedented nature of the Commune's revolution which granted it its importance. Its implications were so far outreaching Marx realized that albeit its deficiencies, the Commune was the only proletariat revolution which paralleled those he had envisaged, such that it needed his wholehearted support.

More importantly, however, was the profound impact the Paris Commune induced on Lenin. Europe was no stranger to revolutions, yet none of the revolutions embodied Marxism. They were either too national (Lombardy in 1848 and Greece in 1821), too liberal (Spain in 1820), or a combination of both (German state in 1848). [1] On the other hand, the Paris Commune offered an unseen Marxist revolutionary model. More significantly, the revolution offered a model which resembled the historical context of early 1900s Russia. The relevance of the Commune to Lenin's historical background and its exclusive portrayal of a Marxist revolution bolstered its significance to Lenin.

Vladimir Lenin was obsessed with the Paris Commune. From his writings to his actions, Lenin manifested his devotion towards the Commune and the astonishing impacts it cultivated. Lenin's admiration towards the Commune and its profound impact on him is evident throughout his writing. In his writings, Lenin stated that "our attitude towards the state and our demand (is) for a 'commune state,' that is a state of which Paris
Commune was the prototype." [4] This quote evidently displays Lenin's admiration towards the Commune as a predecessor to the Russian state he aimed to create.

Moreover, the Commune's extensive impact on Lenin may also be identified through his actions. On the seventy-third day after the October Revolution in 1918, Vladimir Lenin left his Petrograd office early to dance in the snow. His jubilant act was performed as a celebration that the Soviets outlived the Paris Commune. During Lenin's address to the Third All Russia Congress of the Soviets five days later, he claimed that the Soviets had outlasted the Paris Commune because of the "more favorable circumstances" in which the "Russian soldiers, workers and peasants were able to create the Soviet Government." [5] These actions support the previous conclusion that Lenin viewed the Commune as an inspirational predecessor with profound impacts on him.

More notably, however, was Lenin's systemic address of the Paris Commune in his work "The State and Revolution," written between August and September 1917, slightly before the November revolution. The proximity of the two events suggests the publication's close relevance to Lenin's actions. Within his writing, Lenin stated that "he (Marx) regarded it as a historic experience of enormous importance, as a certain advance of the world proletarian revolution, as a practical step that was more im-portant than hundreds of programs and arguments." [6] Lenin himself expressed his affirmation of Marx's view of the Commune, suggesting the importance of the Commune to Lenin's ideology and its relevance to the 1917 November Revolution.

Despite Lenin's approval of the Commune, he believed that its eventual defeat stems from two fatal mistakes: Excessive nationalism and moral magnanimity - all engendered from the Commune's indecisiveness. The lack of decisiveness from the Commune led Lenin to conclude that, "deserted by their allies of yesterday and supported by no one, the Commune was doomed to inevitable defeat." [7] In light of the Commune's failure, Lenin tried to rectify its mistakes via his organization of 
the Russian Social Democratic Labor Party (Bolshevik) party and the coordination of the 1917 Revolution.

To begin with, Lenin believed that the commune "allowed itself to be led astray by dreams of establishing a higher justice in the country united by a common national task; such institutions as banks, for example, were not taken over, and Proudhonist theories about a just exchange, etc., still prevailed among the socialists." [8]

Lenin's viewed translated to his decisive coordination of the 1917 revolution, which aimed at the seizure of national tasks early on. In the early mornings of November 7, 1917, A small group of Bolshevik Red Guards moved into the city. They had one goal: Seizing national institutions. The Red Guards took control of the central telegraph station, railway station, telegraph station, bridges, as well as the State Banks, which the Parisians had failed to capture decades ago. At 9:00 pm on November 17, the soldiers from battleship Aurora, supporters of the Bolsheviks, fired the first shot, initiating the storming of Winter Palace. The Bolsheviks stormed through the building quickly with machine guns and arms, encountering the Women's Death Battalion who surrendered without resistance. Eventually, the Bolsheviks surrounded the meeting room that hosted the Provisional Government, militarily forcing their surrender. [9] The decisiveness in Lenin's seizure of power and its emphasis on seizing national institutions may be best understood as Lenin's efforts to learn from the failures of the Paris Commune.

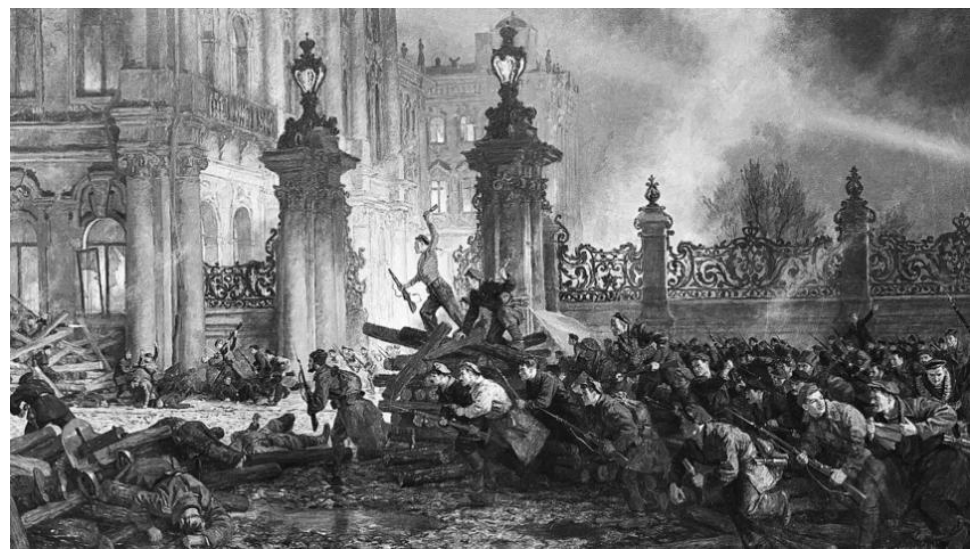

Figure 2. Storming of the Winter Palace during the 1917 November Revolution

In addition to excessive nationalism, Lenin attributed the Commune's failure to its unconsolidated support and wavering aims. Lenin stated that the movement itself was confusing and messy. It comprised patriots hoping to renew the war with Germany, small shopkeepers who desperately required an extension on their debt payment, and some bourgeois republicans. [7]

The Commune's indefinite support base led itself astray from its primary goal: seizing power. Lenin believed that instead of forcefully ousting the Versailles government via a resolute offensive, the Commune was led astray by its ultraistic character as it tried to convert its enemies morally. In doing so, the Commune gave the
Versailles government the chance to regroup its forces, which ultimately contributed to the Commune's downfall during the Bloody Week of May. [8]. With the chance of power seizure now long gone, the Commune's unconsolidated supporter base began to tremble, ensuing its disintegration. Lenin acknowledged that the pettybourgeoisie and bourgeois republicans soon parted from the Commune when they realised its inevitable defeat. "Only the workers remained loyal to the Commune to the end." "(The French proletariat) supported their Government fearlessly and untiringly, they alone fought and died for it, for the cause of the emancipation of the working class, for a better future for all toilers." [7]

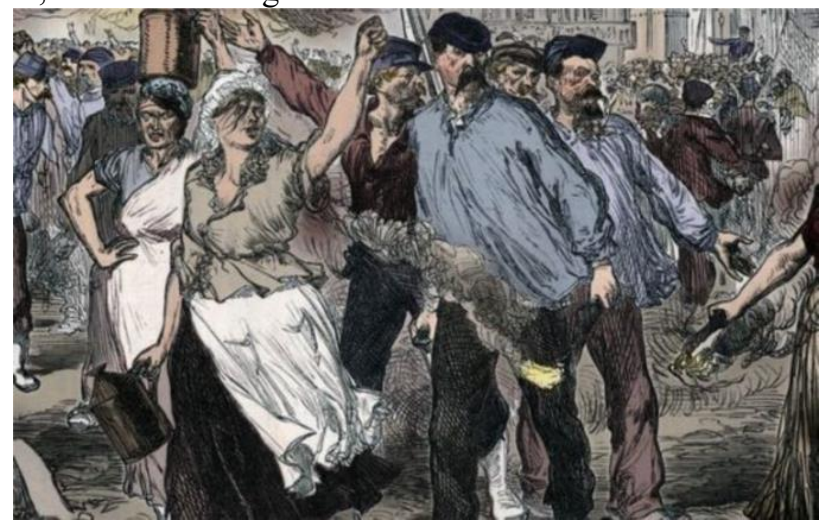

Figure 3. Participants of the Paris Commune from all walks of life 
Acknowledging the Commune's mistakes, Lenin believed that a party that upheld loyalty and obedience, where the lower ranks obeyed and executed the orders of the upper ranks, was required to compensate for the defections of the petit bourgeoisie. [1] This inspired his vision of an elitist revolutionary party: The Bolshevik party and vanguardism. In Lenin's vision, a successful revolution must be led by a group of revolutionary elitists determined and enduring, contrary to Mensheviks envisioning a mass revolution that comprised the bourgeoise, as was the case in Paris.

Upon the arrival of Lenin in Petrograd in April 1930 from Switzerland, he immediately announced in the April Theses that no support was to be offered towards the Provisional Governments, whose attempts to annex the nation were to be recognized and deterred against. [10] Lenin was fiercely attacked by many within the party who believed that support of the mass was a prerequisite for a successful revolution. When the Committee met, Lenin's proposal of an immediate revolution was refuted by four votes to six, with six abstaining. On October 24, Zinoviev and Kamenev, leading Bolsheviks, wrote to Lenin, "To call at present for an armed uprising means to stake on one card not only the fate of our party, but also the fate of the Russian and international revolution... we are convinced (that) the majority of peasants will vote for the Socialist Revolutionaries... if we take power now and are forced to wage a revolutionary war, the mass of the soldiers will not support us." [11] In retrospect, Zinoviev and Kamenev were right; in the 1917 November election, the Bolsheviks only obtained 175 seats, less than half of the 370 seats won by the Socialist Revolutionaries. While Zinoviev and Kamenev were right, so was Lenin. Lenin realized that a revolution's success did not depend on the mass's support. I argue that this ideology he held firm against his own party members stems from his observations of the Paris Commune.

\section{CONCLUSION}

Overall, the Commune, despite its eventual failure and short existence, produced immeasurably impacts on the ideologies of Lenin. Most significantly, Lenin's attribution of the Commune's failure on excessive nationalism and moral magnanimity inspired Lenin that the revolutionaries have to act forcefully and violently, which he demonstrated in the organization of the Bolsheviks party and the administration of the 1917 November Revolution.

\section{REFERENCES}

[1]. Bergman, Jay. "The Paris Commune in Bolshevik Mythology." The English Historical Review 129, no. 541 (2014): 1412-441. Accessed August 3, 2021. http://www.jstor.org/stable/24474120.
[2]. Greeman, Richard. "The Permanence of the Commune." The Massachusetts Review 12, no. 3 (1971): 388-96. Accessed August 7, 2021. http://www.jstor.org/stable/25088132.

[3]. Willimott, Andy. "The Paris Commune Taught the Bolsheviks How to Win a Revolution." Jacobin, March 18, 2021 https://jacobinmag.com/2021/03/paris-communebolsheviks-win-a-revolution.

[4]. Chattopadhyay, Paresh. "Lenin Reads Marx on Socialism: A Brief Note." Economic and Political Weekly 47, no. 50 (2012): 65-68. Accessed August 5, 2021. http://www.jstor.org/stable/41720468.

[5]. Tricontinental: Institute for Social Research. "Lenin Went to Dance in the Snow to Celebrate the Paris Commune and the Soviet REPUBLIC: The TwentyFirst Newsletter (2021)." Tricontinental, May 31, 2021.

https://thetricontinental.org/newsletterissue/21paris-commune/.

[6]. Lenin, Vladimir. "The State and Revolution: Experience of the Paris Commune of 1871. Marx's Analysis." The state and revolution - Chapter 3. Marxist.org. Accessed August 5, 2021. https://www.marxists.org/archive/lenin/works/1917 /staterev/ch03.htm

[7]. The Militant "Lenin on the Paris Commune." Lenin on the Paris Commune (April 1911), October 24, 2020.

https://www.marxists.org/history/etol/newspape/the militant/1932/no12/lenin.htm.

[8]. Lenin, Vladimir. "Lessons of the Commune." Lenin: Lessons of the Commune. Marxist.org, 2004. https://www.marxists.org/archive/lenin/works/1908 /mar/23.htm.

[9]. Fiehn, Terry. Russia \& The USSR: 1905-1941: A Study in Depth. London, England: Hodder Education, 2016.

[10].Lenin, Vladimir. "The Tasks of the Proletariat in the Present Revolution (A.k.a. the APRIL THESES)." Marxists Internet Archive, 2005. https://www.marxists.org/archive/lenin/works/1917 /apr/04.htm. Accessed July 18, 2021

[11].Trotsky, Leon. "Chapter 6 on the Eve of the October Revolution - the Aftermath." Leon Trotsky: The Lessons of October (Chap.6). Marxist.org, January 19 , 2007. https://www.marxists.org/archive/trotsky/1924/less ons/ch6.htm. Accessed July 19, 2021 